\title{
Ocio, placer y (auto)movilidad en la construcción simbólica de los "alrededores de Santiago"
}

Tomás Errázuriz. Universidad Católica del Maule, Talca, Chile.

RESUmen | Partiendo del entendido de que la vida urbana puede extenderse a los territorios extraurbanos antes de que estos sean construidos e incorporados a la trama, se estudiarán los paseos de ocio a las afueras de Santiago, que se volvieron recurrentes gracias a los medios de transporte motorizados durante el primer tercio del siglo xx. Se propone que los nuevos destinos de las prácticas del ocio en los extramuros de la capital tuvieron un rol fundamental en la valorización y difusión de un paisaje de los "alrededores" de Santiago. Como antesala para algunos de los valores que impulsarían el proceso de suburbanización, este paisaje se construyó bajo la lógica de la contraposición ciudad/campo, donde el primer polo representaba la rutina, el trabajo, la agitación, el nerviosismo y, en último término, la corrupción; mientras el segundo, la posibilidad de escape, respiro o descanso de los males del primero.

PALABRAS CLAVE | historia urbana, movilidad, relación campo-ciudad.

ABSTRACT | Based on the understanding that urban life can be extended to non-urban areas before they are constructed and incorporated into the urban fabric, this paper studies leisure trips to the outskirts of Santiago that became recurrent thanks to motorized transportation during the first three decades of the twentieth century. It is proposed that the new destinations for leisure practices played a crucial role in the symbolic construction of the landscape of the outskirts of the city. As a prelude to some of the values that would drive the process of suburbanization, this landscape was built under the logic of the opposition between city and country, where the former represented the routine, work, agitation, nervousness and ultimately corruption; while the later, the possibility of escaping, a breath or a break from the evils of the city.

KEYWORDS | urban history, mobility, countryside-city relationship.

Recibido el 2 de febrero de 2015, aprobado el 6 de noviembre de 2015

E-mail: sterrazur@ucm.cl 


\section{Introducción}

Raymond Williams (2001) se detiene largamente en la construcción del idilio campesino, de la nostalgia de la vida rural y las transformaciones y adaptaciones que los territorios extramuros van experimentando en paralelo a las nuevas formas de vida urbana. Este autor sostiene, con base en el caso de Londres, que el paisaje del campo surge a partir de una distancia social que genera una representación imaginaria del mundo rural, la cual tiene por protagonista a un observador desvinculado del ámbito del trabajo agrícola. Se trata de un sujeto ocioso que tiene la facultad de distanciarse de la naturaleza; de una aristocracia urbana que ve en el campo un escenario estético para la distensión. Esta resignificación del espacio rural liderada por una elite urbana que ve en "el campo" un espacio para el ocio y la contemplación no es exclusiva de la capital industrial del siglo XIX, sino que se observa, con variaciones, acompañando los procesos de modernización y reestructuración de las principales ciudades durante fines del siglo xIx y comienzos del xx.

Los procesos de metropolización no solo implican la alteración del número (Romero, 2005) y de la experiencia urbana (Simmel, 2005; Wirth, 2005), sino también inciden material y simbólicamente sobre los territorios aledańos a las ciudades. Con el cambio de siglo se observa, por ejemplo, cómo la proliferación de los nuevos tranvías y alumbrado eléctrico obliga a la instalación de centrales generadoras de electricidad y sistemas de transmisión; cómo el desarrollo industrial y el crecimiento de nuevos mercados de consumo en las ciudades consolida rutas y formas de movilidad alternativas que transforman el espacio rural; o cómo la creciente población favorece una intensificación de las actividades agrícolas e industriales cercanas a la ciudad. Junto con estos cambios materiales, avanza un discurso que refuerza una visión contrastada y muchas veces contrapuesta entre las formas de vida urbana y las de vida rural. De la mano de la modernización y el progreso urbano adquieren cada vez más fuerza los conflictos sociales y ambientales. Por otro lado, el espacio extraurbano es resignificado desde las elites para ofrecer aquello que la ciudad supuestamente había perdido: tranquilidad, seguridad, exclusividad, contacto con la naturaleza y un ambiente libre de agentes contaminantes. Si bien falta investigación sobre el peso de estas imágenes en los procesos posteriores de suburbanización que tuvieron lugar durante el siglo xx, los documentos dan testimonio de la importancia que adquirieron en términos discursivos y mediáticos.

Ahora bien, cabe preguntarse de dónde surgen estas imágenes en contextos específicos como el santiaguino. No basta con reducir el problema a la constatación de un imaginario antiurbano de raíz protestante que se había implantado con fuerza en las principales ciudades del hemisferio norte (Sennett, 1997; Fishman, 1987). Es fundamental, en cambio, no limitarse a los discursos, sino reconocer ciertas prácticas y actores que inciden en la formación de estas representaciones.

El crecimiento de la mancha urbana de la ciudad de Santiago a lo largo del siglo $\mathrm{xx}$ ha sido habitualmente estudiado como urbanización material y definitiva de antiguos terrenos agrícolas. Este proceso se vincula a las sucesivas extensiones de los límites de los planes reguladores, a la capitalización de plusvalías, a las tomas de terreno y a la construcción de viviendas, comercio, industrias, servicios o 
infraestructura vial. Sin embargo, existe escasa atención sobre los procesos previos de exploración y valorización que adquieren estas potenciales tierras urbanas antes de que se planee su incorporación definitiva a la ciudad. No ha sido foco de estudios el lugar que ocupaban en el imaginario de quienes habitaban la capital, aquellas áreas que solían ser antiguamente los alrededores de Santiago y que hoy forman parte del continuo urbano. Los procesos a través de los cuales determinados territorios van siendo incorporados simbólicamente en un imaginario urbano pueden ser interpretados como el primer paso hacia el posterior proceso de ocupación, suburbanización y urbanización. Reconocer las prácticas y representaciones previas asociadas a los territorios aledańos puede entregar claves para comprender decisiones posteriores sobre el modo en que crece la ciudad y la desigual valoración que adquieren esos terrenos en el mercado de tierras.

En este marco, el presente artículo busca profundizar en una de las formas a través de las cuales se construyó y difundió un modo de entender y valorizar los alrededores de Santiago durante el primer tercio del siglo xx. En particular, se refiere a los paseos de ocio a las afueras de la ciudad que comenzaron a hacerse cada vez más recurrentes gracias a las posibilidades de movilidad que ofrecían los medios de transporte motorizados.

Se propone que los nuevos destinos de las prácticas del ocio en los extramuros de Santiago, posibilitados por la propagación de automóviles, tranvías y autobuses, tuvieron un rol fundamental en la construcción y difusión de un paisaje de los "alrededores" de la capital. Como antesala para algunos de los valores que impulsaría el proceso de suburbanización, este paisaje se construyó bajo la lógica de la contraposición ciudad/campo, donde el primer polo representaba la rutina, el trabajo, la agitación, el nerviosismo y, en último término, la corrupción; mientras el segundo, la posibilidad de escape, respiro o descanso de los males del primero. Lugares como Apoquindo, La Reina, Puente Alto, Maipú, Peñaflor, fueron incorporados tempranamente a la ciudad como destinos de fin de semana; espacios de descanso y recreación, necesarios en la lógica del trabajo en la vida moderna.

Con el objeto de entender los alcances que tuvieron las prácticas ociosas en la construcción simbólica de los alrededores, se estudiarán, en primer lugar, las formas predominantes de sociabilidad de las elites santiaguinas en las décadas de finales del siglo xIx y comienzos del xx, y las nuevas opciones que comienzan a surgir con la incorporación de los vehículos motorizados. Se abordará el paseo o excursión a los alrededores como testimonio de un nuevo modo de ocio vinculado a la vida moderna que comienza a desarrollarse durante las primeras décadas del siglo xx. Se estudiará este fenómeno en asociación con la dialéctica ciudad-campo y la importancia que ella adquiere en la vida cotidiana de los citadinos. Luego se revisará cómo se desarrolló y difundió esta cultura turística del viaje al campo, con especial foco en el uso del automóvil, abordándose aspectos como el valor que adquiere el disfrute de la naturaleza y el registro de las experiencias de viaje en distintos formatos (verso, prosa, fotografía).

Posteriormente, se explorará específicamente cómo, a partir de la segunda década del siglo $\mathrm{xx}$, los automovilistas santiaguinos comienzan a explorar y conquistar los alrededores de la capital. Se identificarán algunos de los principales inconvenientes 
y dificultades que debieron enfrentar y cómo comienza a aparecer una incipiente infraestructura turística y de servicios (termas, balnearios, restaurantes), así como diversas formas de registro de las prácticas turísticas; adicionalmente, se verá cómo, de la mano del mejoramiento caminero, el paseo campestre se vuelve una práctica habitual hacia finales de los años veinte.

Finalmente, se sugieren posibles vinculaciones entre el descubrimiento ocioso de los alrededores de Santiago y el proceso de suburbanización y capitalización de plusvalías que lo sucede. Ambas tendencias comparten ideales modernos en donde se separa ocio de trabajo, vida pública de vida privada, ciudad y campo

Esta exploración en las prácticas del ocio de comienzos del siglo pasado se realizará con base en material recopilado de diversas revistas de época, junto con material fotográfico y guías turísticas.

\section{Antiguas y modernas formas de ocio}

En el estudio de Barros y Vergara (2007) sobre el modo de ser de la alta sociedad chilena hacia 1900 , se abordan con especial interés las nociones de ocio y trabajo en este grupo como un factor determinante de la vida urbana. Luego de una revisión de fuentes literarias de época, los autores sostienen que la oligarquía atribuía un carácter negativo a cualquier forma de trabajo remunerado, siendo la vida ociosa la principal actividad cotidiana. Una holgada situación económica, fuese real o aparente, distinguía a la oligarquía por su posibilidad de prescindir de un trabajo diario. Que trabaje el que requiera el dinero y que se distinga quien no tiene necesidad de este, parecía ser la consigna.

El paseo y los destinos que emprendían diariamente quienes concentraban los poderes económico y político en los años del cambio de siglo seguían las tendencias que habían sido delineadas por las elites en las principales metrópolis del mundo. El parque, el teatro, la ópera, el paseo por el centro y la misa de 12 (en aquellos lugares donde aún primaba el catolicismo) constituían algunas de las principales actividades en torno a las cuales se estructuraba el día de los integrantes de la alta sociedad. El objetivo fundamental de este paseo no estaba necesariamente en el destino o actividad específica al cual se acudía, sino más bien en el hecho de reconocer y ser reconocido por sus iguales. Es sugerente, en este sentido, la aproximación que Edwards Bello (1931) hace a este fenómeno en una de sus novelas, cuando describe las dinámicas que se daban en el principal salón de espectáculos de la capital.

El Teatro Municipal en noches de ópera presentaba un aspecto deslumbrador; dejaban la sala iluminada durante la función de manera que el público pudiera observarse a su antojo. (p. 103)

El posicionamiento de este espacio como un destino de moda relega el goce estético o intelectual del eventual espectáculo a un terreno secundario. En correspondencia con esta finalidad, era esperable que el consumo que prescribía la moda se efectuara en forma colectiva, de manera de ser presenciado por otros (Barros \& Vergara, 2007). Otro destino que era intensamente frecuentado por la elite santiaguina, también descrito por Edwards Bello (1931), fue el parque Cousiño. 
Un día claro y templado me tomó del brazo y me dijo:

-Vas a comprarte un tongo.

Me llevó a una tienda del Pasaje Matte y me hizo escoger uno de los mejores. En la tarde alquiló una victoria y fuimos al Parque. Comenzaba la primavera con un aire claro, dorado. Era ese un paseo de coches transido de afectación; las damas parecían figuras de cera, saludando con cuerda, luciendo vestidos caros. Una iba ensuciándose la cola con el roce de la rueda.

—Es muy rica — me aseguró Bernal.

Cuando obscureció, todos los coches zarparon al mismo tiempo a gran velocidad, permitiendo a esa gente que tomara posturas cómodas. Entraban nuevamente a la ciudad por la calle Dieciocho tras de cuyas celosías moras los ojos expiaban [sic]. (p. 106)

No era la finalidad del paseo al parque el disfrute de la naturaleza, del paisaje o de la vida al aire libre, y si estos motivos existían, eran ciertamente secundarios. Con una coincidencia casi cronometrada en las horas de arribo y retirada, la ida al parque era un desfile de coches en donde sus ocupantes exhibían la prestancia de sus cuerpos, la elegancia y valor de sus trajes y accesorios. Era el momento en que se declaraba, mediante el estricto cumplimiento de las normas de distinción, la pertenencia y jerarquía dentro de un exclusivo grupo social. Entendido bajo esta óptica, el paseo al parque no tiene nada que ver con un paseo de descanso y distensión, requiriendo, en cambio, la compostura, el control de los gestos y la observancia cuidadosa de estrictas pautas de comportamiento.

Los primeros automóviles no alteraron la costumbre del paseo, integrándose al desfile como versión alternativa al carruaje. Su número fue marginal durante toda la primera década del siglo xx. Un recuento de los vehículos en circulación hacia 1910 arrojaba un total de 21 automóviles inscritos, en contraste con los 1.951 coches particulares de dos y cuatro ruedas ("El Actual Departamento del Tránsito", 1928). Hacia fines de la segunda década, gracias a la reducción del impuesto de internación de un $60 \%$ a un $15 \%$ y la caída de los precios provocada por la entrada de la industria norteamericana, el automotor privado alcanzaría un gran impulso, llegando a las 3.143 unidades, frente a los coches, que caían a 1.789 (Errázuriz, 2010). Incluso considerando este cambio de escenario, solo unos pocos excéntricos aprovecharon las inquietantes posibilidades mecánicas del nuevo vehículo para explorar nuevos destinos. Lamentablemente para los promotores del automovilismo, aunque las tecnologías cambiaban, las prácticas y los significados asociados a estas no se alteraban con la misma rapidez. De esta forma, aun cuando gran parte de la elite comenzaba a reemplazar sus coches por automóviles, la estructura del paseo con fines de distinción y reconocimiento social permaneció anclada con fuerza en las costumbres de este grupo. En el año de mayor número de ventas de automóviles de la segunda década del siglo, uno de los columnistas de la revista chilena Auto y Aero manifestaba la falta de una cultura turística entre los dueños de automóviles.

Podría decirse que por regla general los clientes chilenos adquieren automóviles por ostentación; pues si se examina detalladamente el uso que de ellos se hace, puede 
llegarse a la conclusión de que aquí la gente solamente aspira a ser señalada como que "tiene auto"; sin preocuparse, ni mucho menos tener el premeditado designio de explotarlo en debida forma. ("El camping", 1917, pp. 154-158)

Ciertamente, quien paseara en un automóvil por los alrededores de la ciudad no sería visto sino por los pobladores y uno que otro dueño de fundo. El objetivo de distinción y reconocimiento social, reforzado por el consumo colectivo del bien, debía ser reemplazado por otro en donde primara el placer y la satisfacción individual, ya fuese ante las inéditas posibilidades de desplazamiento o como resultado de la contemplación del paisaje.

En Casa Grande, de Luis Orrego Luco, obra donde se describe con bastante detalle los movimientos de la elite tradicional en la capital hacia 1908, el vehículo de desplazamiento es siempre el coche o carruaje particular. Paradójicamente, el único momento en que aparecen los automóviles es para referirse al arribismo de los nuevos sectores sociales económicamente emergentes que comenzaban a mezclarse con la elite tradicional:

Todos querían ser ricos de golpe, sin trabajo, sin esfuerzo, sin sacrificios de ningún género. Ahí estaban las tres o cuatro fortunas de salitreros y mineros improvisados, exhibiéndose insolentemente, haciendo resonar las trompetas de sus automóviles, derramando el champagne a torrentes, tirando el dinero a manos llenas por la ventana. (Orrego Luco, 1906, p. 16)

La misma revista Zig-Zag, mediante dos portadas publicadas en menos de un año (figuras 1 y 2), da testimonio de la vigencia que aún mantenían los coches particulares, al tiempo que su comparación sugiere las profundas diferencias sociales y culturales entre quienes usan la tracción animal y los que utilizan los vehículos a motor para pasear. Mientras una joven pareja vestida de fiesta y su perro de raza son conducidos por una distinguida auriga en un coche de dos ruedas, la otra pareja viste trajes especiales para resistir el polvo y el viento que conlleva una excursión en automóvil. Mientras la mujer del coche, perteneciente a la tradición del paseo en sociedad, mantiene una delicada quietud alerta a los movimientos de su entorno, la mujer motorizada, en un acto inédito de audacia y libertad, usa la altura que le proporciona el asiento de su automóvil para cosechar frutas de un árbol, que luego ofrece a su pareja, quien observa tranquilo el paisaje circundante.

En fin, más que constituir representaciones específicas de los modos en que se utilizaban los distintos medios de transporte en el país, argumento dudoso debido al probable origen extranjero de estas ilustraciones, lo que interesa es la validación paralela que una revista de elite hace de dos tradiciones con aproximaciones absolutamente distintas al problema del ocio. A la costumbre del paseo de distinción y reconocimiento social que diariamente tenía lugar en los parques capitalinos de moda, se contrapone el paseo o excursión a los alrededores rurales, que se lleva a cabo los fines de semana y los días festivos. Mientras el primero es representativo del "modo de ser" de aquella oligarquía tradicional que renegaba del trabajo como sustento de la vida cotidiana, la segunda se relaciona más con los nuevos grupos medios emergentes, para quienes el paseo constituye una tregua que permite sobrellevar lo que comenzaba a denominarse rutina del trabajo y nerviosismo de la vida urbana moderna. 
FIGURA I Y 2 | Portadas revista Zig-Zag

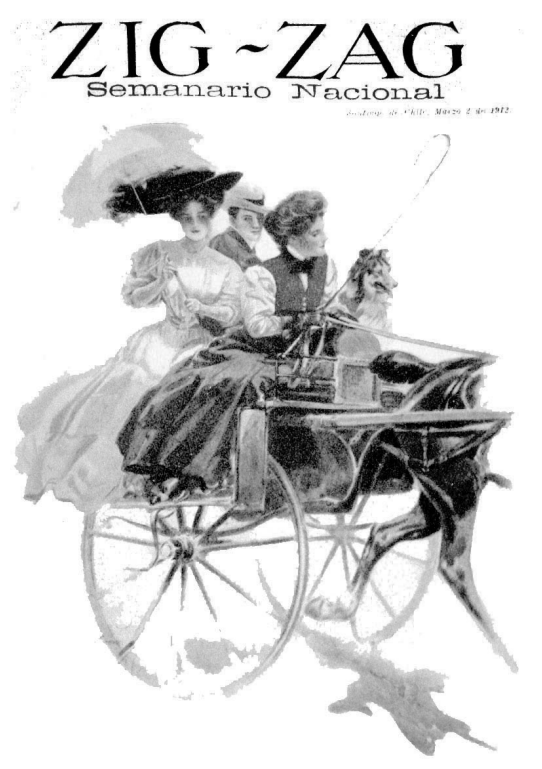

FUENTE ZIG-ZAG. NÚM. 244, I 909

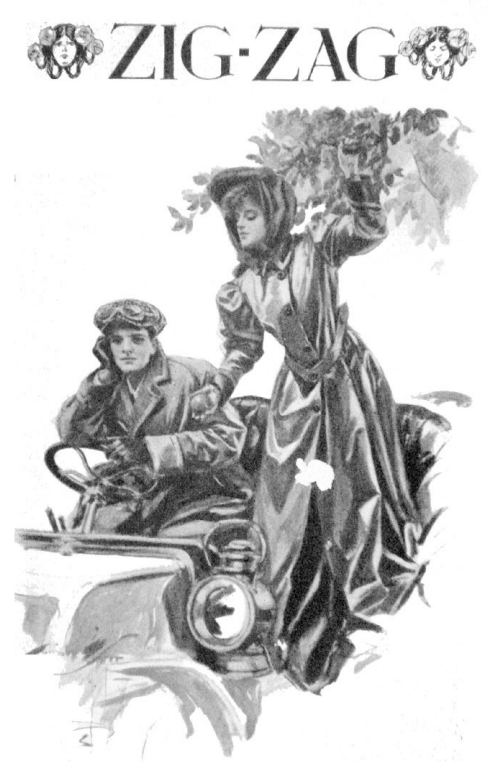

FUENTE ZIG-ZAG. NÚM. 62I, I9I7

Sin embargo, pese a las diferencias evidentes que estas dos tradiciones dan a las actividades de ocio, no es posible comprender ambas de manera independiente. Aun cuando la elite más conservadora no estuviese dispuesta a incorporar prácticas que cuestionaban directamente sus creencias y costumbres, los más jóvenes no siempre compartían el sentido y los valores que habían guiado a sus padres. Por otra parte, los nuevos grupos medios profesionales, con un fuerte componente extranjero, si bien no compartían la procedencia cultural de la oligarquía tradicional, buscaban asimilar parte de sus hábitos y prácticas de manera de legitimarse socialmente. En consecuencia, al intentar comprender el modo en que desarrollaron las nuevas prácticas automovilísticas ociosas hacia los alrededores de la capital, no es conveniente vincularlas directamente a un grupo social específico, sino más bien asociarlas a un nuevo modo de ser que se desenvuelve junto con el desarrollo de las formas de vida metropolitana.

\section{El campo como espacio de placer y libertad}

La dialéctica ciudad-campo, que adquiere un lugar central en el proceso de metropolización, es también fundamental para comprender las motivaciones que originaron la expansión de la geografía del ocio cotidiano desde los espacios tradicionales hacia los alrededores de la capital. Como el lugar de las agitaciones, el tedio, las preocupaciones, la monotonía, el ruido ensordecedor, o de la tristeza del duro 
trabajo cotidiano, es calificada constantemente la ciudad y vida urbana por quienes buscan promover las nuevas experiencias de viaje hacia las afueras de la urbe ("La Agonía del Verano", 1930; "La gente que va al zoo", 1930; "Vamos a la nieve", 1929). En estos discursos, la ciudad funciona como el mal necesario que permite sostener la economía capitalista contemporánea. Dentro de esta lógica, el o los días de descanso constituyen, tal como se señalaba anteriormente, una oportunidad de salir físicamente de la ciudad, disfrutar el paisaje natural y así intentar desconectarse por unas horas de las obligaciones y responsabilidades de la vida diaria.

(...) salgan fuera de la ciudad, más cerca o más lejos, pero donde no llegue el ruido ensordecedor de la ciudad y se respire aire libre. Un día que así transcurra, tonifica los músculos, renueva la sangre, mejora el carácter y deja al individuo en condiciones de entregarse nuevamente a sus habituales y siempre agotadora faena. Hágalo por usted, por su esposa, por su hijo. No deje que la civilización y el progreso encadene, le aplaste y destruya su organismo necesitado de contactos frecuentes con la naturaleza bajo el sol puro y el aire oxigenado de los campos. ("Lo que es el camping”, 1929, p. 494)

$\mathrm{Al}$ campo, como aquel espacio rural en que se está en contacto directo con la naturaleza, se le atribuye una condición sanadora y energizante que permitiría afrontar, semana a semana, las exigencias y el desgaste inherente a la vida que se lleva en las ciudades. Así, en la salida periódica hacia las afueras estaría la clave para alcanzar un cierto equilibrio del organismo. Este discurso no solo fue recurrente en las revistas de automovilistas, sino que también encontraba asidero entre los "chauffeurs" y dueños de automóviles de alquiler, a través de la revista oficial de la Federación de Chauffeurs de Chile. En uno de sus artículos se advertía que el "aire puro", "la tranquilidad de ánimo" y el "regocijo del espíritu” que ofrece el campo, constituían el modo más eficaz para afrontar las tensiones nerviosas del cuerpo y la mente que se producen en el desgaste y esfuerzo diario "de bregar ardorosamente por ganarse el pan" ("Pic Nic con que la federación...”, 1926, p. 11). Esta misma condición purificadora ante la corrupción de la vida urbana aparece en un cuento de la misma revista:

Ella era vendedora de una gran tienda central. Él, chofer; había adquirido su "auto" tras innúmeros sacrificios. El domingo -idomingo: bendición de los pobres!- era para ellos una fiesta alborozada y jubilosa: salían a la campiña y se abandonaban a la ruidosa alegría de su juventud. Por la noche regresaban con el auto lleno de flores y el alma preñada de entusiasmo, de ese entusiasmo necesario para mejor soportar la tristeza del rudo trabajo cotidiano. ("Hallazgo", 1928, p. 15)

Sin embargo, en ese discurso, las bondades del campo para los habitantes de las ciudades no se limitaban a la acción renovadora que tendría el contacto con la naturaleza; también se describían otros beneficios asociados, entre los que destacan los placeres estéticos que se obtienen, primero, de la contemplación e interacción con el paisaje natural; y segundo, de la combinación inédita de velocidad y libertad de movimiento que provee el automóvil a sus ocupantes.

Tal como explica Booth (2009) respecto a las nociones de naturaleza y el week-end en los inicios del automovilismo, la excursión en automóvil, por la forma específica en 
que se recorre el territorio, implica una sensibilización frente al paisaje natural. A diferencia de los viajes en tren, en los cuales se obtiene una visión lateral y limitada sobre el paisaje, a altas velocidades sin detenciones sino en las estaciones y bajo el cumplimiento estricto de un horario, el viaje en automóvil ofrece una nueva experiencia del entorno. El recorrido más bien lento y accidentado al que obligaban los caminos, la visión panorámica sobre los alrededores, la libertad en las decisiones del trayecto y en el número y duración de las paradas, permitieron cultivar una interacción mucho más directa con el medio natural que la que había permitido el viaje en ferrocarril. Por otra parte, la inexistencia de hoteles o residencias en el camino durante las primeras décadas del automovilismo implicaba que todas las necesidades básicas que surgieran en el transcurso debían encontrar acogida en este medio natural.

A través de las primeras revistas de automovilismo y siguiendo las costumbres que se habían propagado en las ciudades donde este vehículo se había instalado con mayor fuerza, los automovilistas chilenos promovieron el gusto por el disfrute de la naturaleza desde el camino.

Son muchos entre nosotros los que saben percibir el "encanto del camino". Esas
carreteras y senderos que serenos y generosos multiplican y desvían su curso en vías
vecinales bordeadas de matorrales y espesuras, o se pierden en caminillos ribetea-
dos de oloroso césped; conducen ora a la floresta sombría, o al picacho escarpado
y soberbio; o bien se pierden entre la haciendas, y llegan hasta la plazuela irregular
de la aldehuela que dormita a la sombra de la iglesita, allá en el fondo de un valle
pintoresco. ("Caminos para automóviles", 1917, p. 91)

Íntimamente ligado a la contemplación y goce del paisaje natural en automóvil, el registro de esta experiencia adquiere un papel fundamental. Aunque la prosa y el verso habían sido hasta entonces el principal lenguaje mediante el cual se daban a conocer y recordaban las actividades que llevaban a cabo las elites, la comercialización de la máquina fotográfica portátil con rollo de película desplegable fue tempranamente asociada a la excursión en automóvil. El tamaño reducido, la sensibilidad de las emulsiones, la prescindencia de las pesadas y frágiles placas de vidrio, eran las principales ventajas que los nuevos aparatos presentaban para el sportman. Entre los numerosos avisos publicitarios que aparecieron desde mediados de la segunda década del siglo, la propaganda de cámaras fotográficas asociadas al uso de automóviles se volvió una estrategia habitual.

Por su parte, para los propulsores del turismo automovilístico y el descubrimiento del territorio nacional, la cámara fotográfica constituía el mejor aliado. La condición mediática propia de la fotografía permitía no solo dejar constancia y registro de los logros alcanzados por los aficionados, sino, además, sociabilizar una actividad que -a diferencia de los paseos de distinción- se efectuaba lejos del reconocimiento social directo de los pares. En otras palabras, el registro fotográfico de un paseo de excursión era la posibilidad de hacer público un evento que generalmente residía en el ámbito de lo privado. Hacia 1927, el principal medio de difusión del automovilismo en Santiago sostenía que la fotografía se había convertido en el complemento indispensable del automovilista y que " $[\mathrm{h}]$ oy día nadie concibe un viaje de turismo 
en automóvil sin las correspondientes vistas de los sitios visitados y de los caminos recorridos" ("Guía del Automovilista", 1920, p. 91).

Una popular guía para automovilistas reservaba una de sus secciones a la importancia de la fotografía para el turismo en automóvil. Además de detallar las características técnicas que debía cumplir una cámara, se especificaba cuidadosamente la manera en que se debían tomar las fotografías para obtener un resultado armonioso y atractivo.
El primer plano debe ocupar siempre un cuarto de la altura de la vista, salvo en vistas tomadas desde lo alto. Aténgase usted a esta regla y desde luego habrá ganado en la conformación de su foto. Aun cuando se trate de un simple paisaje, es indis- pensable que haya a cierta distancia cercana al objetivo un sujeto principal, sea un rancho, un árbol, una roca, etc. Esto da un sentido práctico de mucho efecto. El sujeto cercano puede ser cualquier cosa, no es preciso que sea una persona. Hemos visto hermosas vistas que tenían por todo sujeto principal ante un paisaje bellísimo la silueta de un poste telefónico...
Es entendido que si el sujeto puede ser una persona ante un paisaje, el efecto es aun mejor, y si esta persona es una seńorita (por ejemplo), ya no hay nada mejor que pedir. ("Guía del Automovilista", 1917, p. 91)

Finalmente, al placer estético que conlleva el contacto con la naturaleza y su condición revitalizadora ante la tormentosa vida moderna, se suma como motivación el placer de la velocidad y de las condiciones de libertad y autonomía que el viaje en automóvil reporta a sus ocupantes. Esta condición ha sido reconocida por los estudios contemporáneos como una de las bases sobre la cual se ha sentado el sólido vínculo entre automovilistas y automóviles. Ya a fines de la década del sesenta, Baudrillard (1969) afirmaba que el movimiento en sí mismo trae consigo una cierta dicha, pero la "euforia mecánica de la velocidad" constituye algo distinto. Para el autor, esta se funda en el ámbito de lo imaginario y en el milagro de la movilidad sin esfuerzo (p. 71).

A esta dicha generada por la velocidad de los nuevos medios mecánicos se sumaba, en opinión de Baudrillard, su funcionamiento como "extensión del mundo cotidiano privado", lo que en la práctica implica la facultad de trascendencia de lo doméstico hacia dimensiones más abiertas y difusas, sin por ello perder su carácter cotidiano. Otros autores sostienen que hay un nexo crucial entre moción y emoción, o entre movimientos y emociones, y que simples inversiones sinestésicas, desde caminar hasta manejar un automóvil, nos orientan hacia un posicionamiento de nuestro entorno material, generando geografías de la emoción (Sheller, 2004; Thrift, 2004). En 1902 un automovilista escribió: "Viajar significa la máxima libertad de movimiento, el tren, por su parte, te condena a la pasividad... la vía férrea te restringe a un horario" (Urry, 2004, p. 29).

Junto con el aumento del número de automóviles en Santiago a partir de la segunda década del siglo $\mathrm{xx}$, diversos promotores del automovilismo llamaban a los dueños de vehículos a descubrir las nuevas experiencias que ofrecían los automotores en comparación con las antiguas victorias. Utilizar el automóvil para realizar los mismos paseos que tradicionalmente habían sido efectuados en coches de tracción animal, era desaprovechar un vehículo cuyas características técnicas prometían 
revolucionar las formas de desplazamiento. Bajo este entendimiento, el parque, el paseo al centro, la ida a la ópera o al biógrafo, debían ceder su predominancia como destinos frente al recorrido sin limitación que se extendía hacia las afueras de la ciudad. Era en "los alrededores" de la ciudad donde el uso del automóvil adquiría mayor sentido, donde las inéditas posibilidades de desplazamiento se evidenciaban más claramente y donde el automovilista podía experimentar las nuevas sensaciones de velocidad, autonomía y libertad. Un automovilista afirmaba al respecto:

A caso lo que más propende al cultivo del espíritu, al desarrollo de los sentimientos, son las excursiones. (...) En las horas dedicadas al descanso, cuando el alma siente las ansias de mirar al frente a la naturaleza, nada hay más hermoso y bello que sentir el vértigo de la velocidad en medio de la llanura, bajo la sombra de los bosques o en las laderas de las montañas. ("Las excursiones", 1916, p. 197)

El "vértigo de la velocidad" al cual aluden este y otros automovilistas chilenos del período debe ser interpretado cuidadosamente. Ya hacia la segunda década del siglo xx, los nuevos modelos de automóviles eran capaces de desarrollar velocidades superiores a 90 kilómetros por hora en condiciones ideales. Ahora bien, ciertamente esas condiciones ideales no existían aún en Chile, donde los caminos de tierra eran superficies labradas por el clima que obligaban a controlar la marcha para evitar accidentes o la descomposición del vehículo. Sin embargo, considerando que las velocidades máximas a las cuales podía tener acceso un habitante en sus recorridos habituales, previo a la adquisición de un automóvil, no superaban los 30 a 35 kilómetros por hora, y si sobrepasaban este límite, lo hacían en el espacio cerrado y controlado del ferrocarril, resulta factible comprender la experimentación del "vértigo de la velocidad" que puede haber significado alcanzar velocidades cercanas a los 50 kilómetros por hora en un vehículo descubierto y sobre un camino irregular.

Pero no todos los dueños de automóviles tenían el espíritu de aventura suficiente para hacer frente a las contrariedades originadas en el mal estado en que se encontraban los caminos hacia los alrededores de Santiago, o a los imprevistos que comúnmente surgirían durante el trayecto. La pavimentación de caminos en los alrededores de Santiago recién entraría a la agenda pública bajo el primer gobierno de Ibáñez del Campo a fines de los años veinte (Errázuriz, 2014). Un paseo a Lo Espejo en 1914 dejó “[t]reinta automóviles inutilizados (...), cien neumáticos perdidos y otros panes y descomposturas que significan a los asistentes en automóvil no menos de diez mil pesos en pérdidas". Además de lo intransitable del camino, los automovilistas protestaban por las molestias ocasionadas por los conductores de vehículos de tracción a sangre y las carreras y el andar errante de numerosos huasos que transitaban ebrios por los caminos (“¡Pobres automovilistas!”, 1914). Pese a los inconvenientes, los más fanáticos promovían la instauración de una cultura turística que se impusiera frente a la comodidad y cobardía que reconocían en sus dueños.

— ¿Usted no sale de Santiago? Hay un minuto de vacilación y luego:

-No..., nunca.

Así hay muchos. Tienen automóvil para... acercarse cada mañana al Correo y visitar los domingos el biógrafo, a las 6 ... Fuera de ese estrecho marco de diversión, nada... 
Sin el gasto de un chauffeur existe el temor ridículo de una panne que necesariamente DEBE producirse en el camino...

Yo he instado a mi amigo para salir los domingos y sólo después de una carga sistemática, consigo que salgamos por ahí... cerquita... por si acaso se descompone el auto...

Son inútiles las declaraciones que, ahora, con los adelantos modernos, los motores a explosión han adquirido un grado tal de perfección que la posibilidad de una parada forzosa desaparece rápidamente. Sin embargo, los viejos sentimientos timoratos predominan... Que el cuento de una desgracia acaecida a Fulano...; que el coche de Zutano se descompuso y hubo de recurrir a la mansedumbre de los bueyes...; que más allá Perengano cayó a una acequia cubierta y ahí fue el apuro...

La serie continúa y sólo después de una explicación que nadie entiende, porque la reflexión la subordina al miedo, consigo con uno de los tantos miedosos que vamos a... Recoleta afuera. ¡Nada más!

(...) No ha habido contratiempos. Mi amigo se envalentona. Me invita a otro raid por un lugarcito más lejano... no mucho... (Dell'Orto, 1920)

\section{La construcción turística de los alrededores}

Pese a la insistencia de los más fanáticos del automovilismo por difundir el viaje de turismo en automóvil como alternativa de descanso frente a los paseos de distinción, la asistencia a salas de espectáculo o la permanencia en los hogares, esta práctica no pareciera haber tenido mayores repercusiones hasta avanzada la década de 1920 . Si bien el automóvil tipo "turismo", descapotable para cinco a siete personas, era el modelo más frecuente entre los santiaguinos, el paisaje de los alrededores como destino turístico recién comienza a ser un escenario de la propaganda automovilística una vez que se han establecido ciertos destinos seguros y los caminos han comenzado a ser materia de preocupación del gobierno y las autoridades locales. No es la excursión con rumbo incierto y espíritu aventurero la que se populariza finalmente entre quienes buscaban salir a los alrededores durante los días de descanso, ni tampoco es el camping o la búsqueda del paisaje puro y sin huellas de civilización. En cambio, el paseo a los alrededores que se vuelve cada vez más frecuente es aquel al cual se llega de manera relativamente segura y programada y que tiene por destino un lugar con ciertas instalaciones que permiten a los viajeros mantener un mínimo de las comodidades a las cuales están acostumbrados en su vida citadina.

Santiago posee la materia prima en abundancia: paisajes de primer orden, una naturaleza rica en bellezas, pero sólo ahora se comienzan a comprender las ventajas de contar en las cercanías de la capital con establecimientos dotados de todas las comodidades modernas donde ir a buscar descanso y salud. ("Balneario de Apoquindo", 1921)

Reinaugurados en diciembre de 1921, los conocidos Baños de Apoquindo dieron inicio a la temporada de verano organizando un gran encuentro que congregó a 
¿A dónde pasará usted el próximo domingo?

A pocos minutos de Santiago, y con todas las ventajas del más refinado

Balneario europeo, se encuentran los bańos de Apoquindo.

Hermosos campos, aires puros y una espléndida cocina, hacen de

Apoquindo el lugar preferido de los santiaguinos.

No pierda el tiempo; tiene usted el sitio de veraneo casi al lado de su casa.

VISITE LOS BAÑOS DE APOQUINDO.

(“Baños de Apoquindo", 1927 p. 7)

destacadas figuras del mundo social, político y diplomático, sumando en total más de mil personas. Unos años más tarde, un aviso publicitario interpelaba a quienes buscaban el descanso en las afueras de la ciudad.

Para quienes no tuviesen automóvil, existía un servicio de autobuses que en treinta minutos recorría los 14 kilómetros que separaban estas instalaciones de la Plaza de Armas (García Díaz, 1929). Una alternativa a estas instalaciones termales eran los baños de Colina, situados a 19 kilómetros de Santiago por un camino que se extendía por cerca de una hora. Otro establecimiento que captó a quienes buscaban salir de la ciudad en los días de descanso fue el Parque Sportivo de Pudahuel. Ubicado a 12 kilómetros de Santiago, a media hora en automóvil y 45 minutos en ferrocarril, este establecimiento contaba con servicio de restaurante, una laguna con botes de remos y motor, abastecimiento de bencina, neumáticos y accesorios, y hacia 1917 anunciaba la pronta inauguración de canchas de tenis, fútbol y bochas ("Parque Sportivo Pudahuel", 1917; "Vida Automóvil", 1917). A mayor distancia, pero también muy concurrido, se encontraba el Balneario de Jahuel. Ubicado a una hora de San Felipe y en los faldeos de la Cordillera de los Andes, destacaba por la combinación de un hermoso emplazamiento y cómodas instalaciones (piscina, restaurante, alojamiento). Mientras los que no tenían automóvil tenían la posibilidad de tomar el expreso de Santiago o Valparaíso y luego ser recogidos en San Felipe por un automóvil del balneario, los automovilistas debían recorrer 107 kilómetros y cruzar la cuesta de Chacabuco, trayecto que tenía una duración de cuatro horas y media (García Díaz, 1926, p. 376). A estas instalaciones turísticas se debe agregar la incipiente oferta hotelera y gastronómica que comenzaban a brindar otros destinos muy frecuentados en los alrededores de Santiago, como era el caso del Cajón del Maipo y Peńaflor ("Las excursiones...", 1927, noviembre-diciembre; "Vida Automóvil...", 1917, noviembre).

Si bien en su mayor parte estos lugares existían como destinos turísticos antes de que el automóvil se asociara al paseo por los alrededores, y se llegaba a ellos por tracción animal o ferrocarril, la disminución de las distancias que permitieron las nuevas tecnologías y la propagación de una cultura turística entre un cierto grupo de santiaguinos, aumentó significativamente la demanda sobre estos destinos y el valor que adquirieron para la población. Centros termales que tradicionalmente habían servido como sedes de sanación para diversas enfermedades se transformaron en centros turísticos donde incluso, en algunos casos, se prohibía el acceso a los enfermos. Algunos pueblos cercanos a la capital que habían servido de balneario para capear los meses de verano, ahora eran destinos de visitas diarias o por el fin de semana. La comparación 
entre las guías turísticas Baedeker de Chile, publicadas en 1910 y 1930, es ilustrativa de este proceso. En solo dos páginas y con un marcado énfasis en los aspectos prácticos, como las tarifas, las distancias y los tiempos, se resume el apartado "Santiago y sus Alrededores” en la guía de 1910. En cambio, en la de 1930, el ítem dedicado al turismo comprende casi veinte páginas, incluyendo mapas, detalles de los recorridos y destinos, y una división entre viajes cortos, largos y aquellos que se realizan hacia el sur del país (Sociedad Editora Internacional, 1910; Tornero, 1930).

Las asociaciones de automovilistas tomaron el liderazgo en la difusión y promoción del paseo a los alrededores de Santiago con motivos turísticos. La revista Auto y Aero no solo publicaría los testimonios e imágenes de los viajes de sus afiliados, sino que hacia 1920 lanzaba en dos volúmenes El libro azul, una guía para automovilistas en la cual se detallaban una a una las rutas y paseos que podían realizarse hacia los alrededores de Santiago. Además del plano base con el resumen de los recorridos turísticos que se ilustra en la figura 3, se entregaban otros ocho mapas correspondientes a la extensión de estas rutas en las distintas direcciones. Al comparar este mapa turístico con el levantamiento de los caminos alrededor de Santiago para 1914 (figura 4), es posible apreciar el trabajo de estudio y selección de rutas con potencial turístico que se efectúa en esta guía para el automovilista. Por otro lado, la densa red caminera que se traza en este levantamiento da cuenta de las múltiples posibilidades que tenía la excursión en automóvil hacia las afueras de la ciudad.

Otra publicación que fomentó insistentemente el viaje a los alrededores fue la revista Motor, publicada entre 1925 y 1930. Durante los primeros ańos y luego en forma interrumpida, se publicaba una sección titulada "Nuestros domingos por los alrededores de Santiago", en la cual se relataba e ilustraba en forma extensa y detallada el viaje de automovilistas a distintos destinos de interés en las afueras de la capital. Una sección del primero de estos artículos, dedicado al sector de Apoquindo, permite apreciar las motivaciones e intereses tras estos viajes. 
FIGURA 3 | Mapa de los alrededores de Santiago de 1920

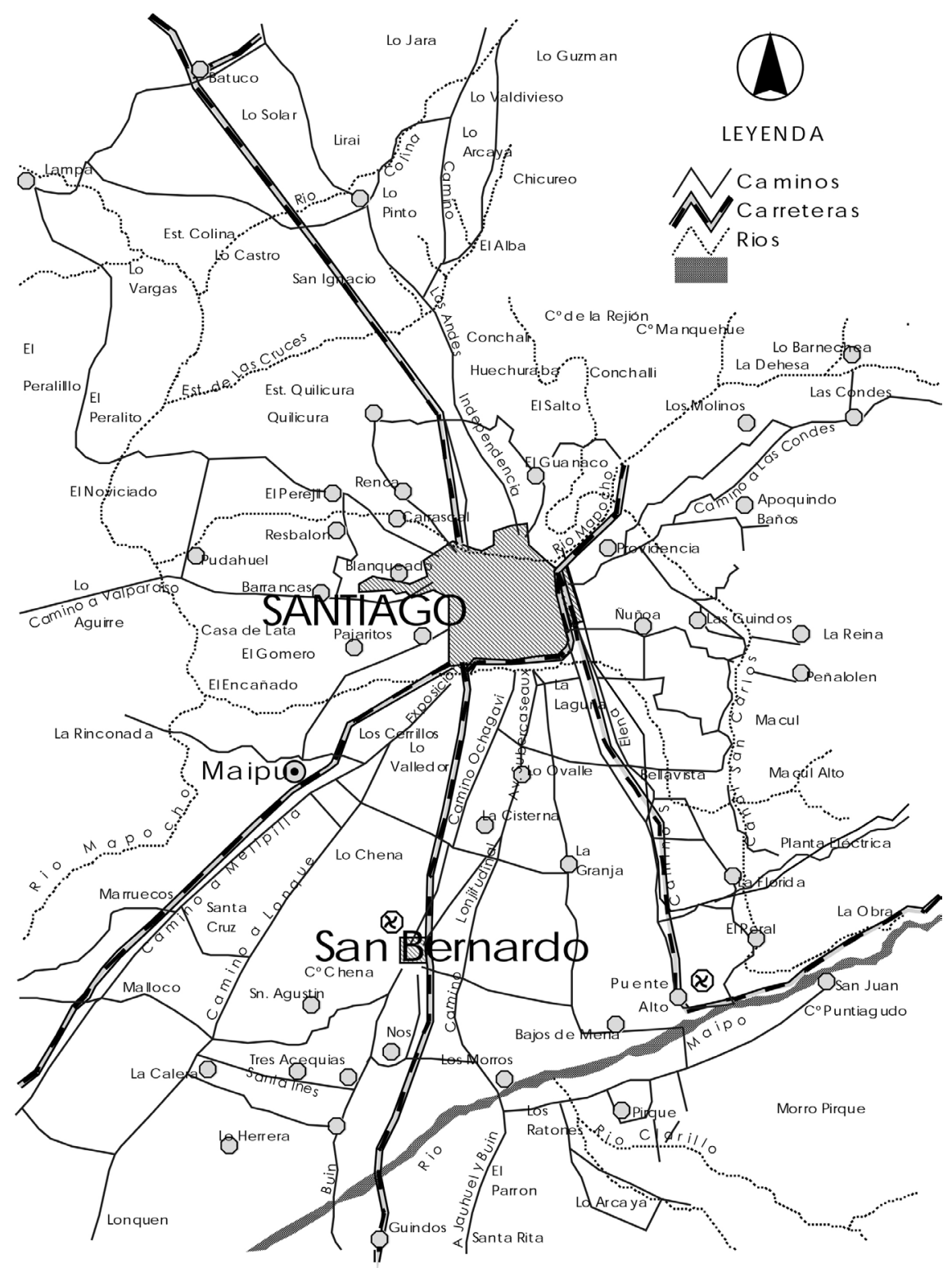

fuente Guía del automovilista (santiago de Chile: auto y Aero, I920). DIGITALIZACIÓN: JENNIFFER THIERS 
FIgURA 4 | Caminos en los alrededores de Santiago hacia 1914

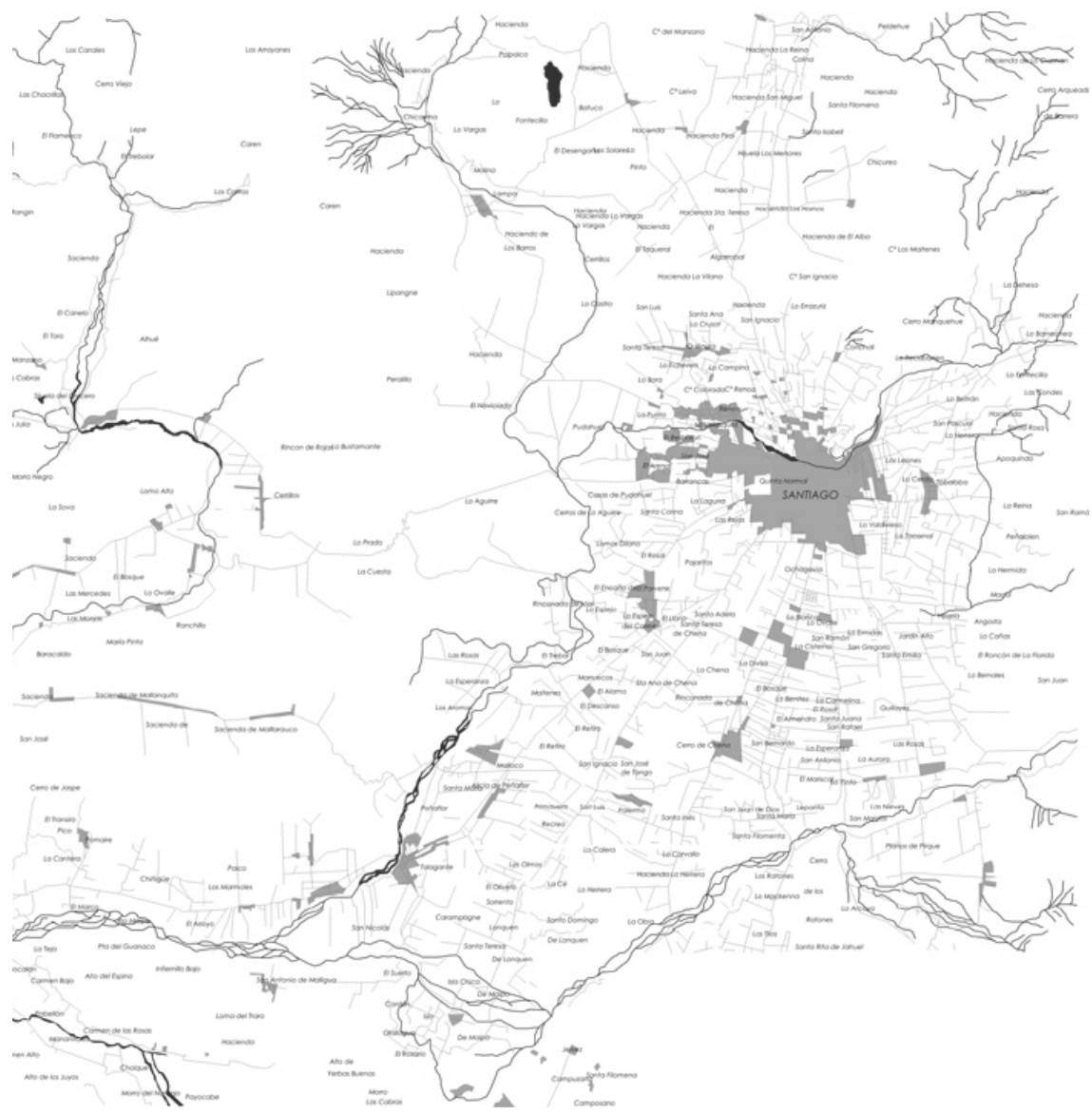

FUENTE FACILITADO POR RODRIGO BOOTH. MAPOTECA DE LA LIBRARY OF CONGRESS. DIGITALIZACIÓN: JENNIFFER THIERS

Vamos hacia la Plaza Italia. Una parada, unos cuantos litros de bencina y doblamos primero por la avenida Vicuña Mackenna, tomando el camino por Ñuñoa (...) hasta llegar a la Plaza Los Guindos. Es el bien pavimentado y conocido trayecto que bordean numerosos chalets. Debemos internarnos en la avenida Ossa, con suelo pedruzco y arena, bien apisonado, tal vez la parte más pintoresca del trayecto. Sus árboles enormes, dejando colarse entre el follaje rayitos de luz, le dan un marcado aspecto de vía campestre, serena, apacible, pero cuya poesía, al tratar de ser enfocada por la "kodak", se desvanece entre la polvareda de un "folleque" impertinente. (...)

Al final de ella, tres o cuatro virajes y entramos a confundirnos con el camino por Providencia. Es la llegada a Apoquindo, cuyo trecho final, en una extensión de cerca de dos cuadras, tiene una pendiente pronunciada. El Cleveland no solo no 
necesita emplearse, sino llega a tomar carrera, terminando, por último, sobre la explanada frente a la terraza. En total se han hecho unos 18 kilómetros.

Como lo dijimos al comienzo de estas líneas, hallamos buenos panoramas, música, baños termales (de tina y natación), parque, cantina a precios corrientes y, un poquito más abajo, la quinta Santa Nicolasa, donde la "baya" encuentra siempre espíritus que saben justipreciarla. ("Nuestros domingos por los alrededores de Santiago", 1925, pp. 5-7)

\section{El paseo campestre}

Además de las instalaciones hoteleras y termales, la otra modalidad de paseo que se volvió frecuente entre quienes buscaban el descanso del fin semana en los alrededores, fue la del "paseo campestre". Aunque en este caso también es posible encontrar diversos testimonios de paseos hacia los alrededores en coches, ferrocarriles y tranvías de tracción animal, el carácter que adquiere con los vehículos motorizados y de tracción eléctrica toma un signo masivo que responde a motivaciones asociadas al ocio moderno.

Ramón Lira se refiere repetidas veces a la función turística que cumplió el tranvía eléctrico en sus primeros ańos de funcionamiento, contribuyendo a la familiarización con los alrededores de la ciudad como destino ocioso.

...en las noches de primavera, de suave brisa y fresquísimo ambiente, era tradicional costumbre y de rigor que las familias más encopetadas y de buen pasar santiaguinas, no tenían ningún empacho y no se denigraban cuando subían a un viejo y chicharriento tranvía $\mathrm{N}^{\circ} 1$ Alameda, o al № 11 Providencia, con todos sus efectivos descendientes de los blasones tal o cuales, y hasta acoplaba al convite del paseo nocturno tranviario la vieja empleada que cocinaba (...). Las familias salían a dar vueltas en un carro en las noches primaverales, por Providencia, por Nuñoa y hasta se animaban algunas audaces familias a pasar por la avenida Bilbao, poco tiempo después que se pusieron de actualidad las victorias y los coches Dumont. (Lira, 1955, pp. 131-132)

Frente al aire de rareza que aún envolvía a los automóviles, el tranvía constituía la última revolución tecnológica en materia de transporte y, consecuentemente, su uso pareciera haber sido capitalizado por miembros de la elite para efectuar viajes exclusivos de placer en las afueras de la ciudad.

La rápida expansión del tendido tranviario por toda la ciudad y los alrededores permitió que se arraigara, entre muchos, la costumbre de utilizar los días domingos y festivos para salir de la ciudad en búsqueda de la paz y tranquilidad que brindaba el contacto con la naturaleza. En su relato sobre la línea No 3 Nunñoa, Lira (1925 pp. 164; 166...) explica que si bien los pasajeros eran la mayor parte del tiempo escasos, los domingos y festivos "su clientela afuerina rebasaba a veces las carrocerías de sus tranvías". Entre los pasajeros había quienes iban a presenciar los espectáculos deportivos que se efectuaban en los Campos de Sports de Nuñoa, pero sobre todo "bullangeros y bulliciosos pasajeros (...). Asiduos clientes dominicales 
de esas famosas Quintas de la antiquísima avenida Ossa de Tobalaba”. Por solo veinte centavos se podía acceder a una de las numerosas quintas que abrían sus puertas a los festivos visitantes. El pago de "la chaucha" les daba derecho a consumir toda la fruta que quisieran hasta saciarse. Como la línea No 3 Nuñoa, también la $\mathrm{N}^{\circ} 23$ Macul llevaba numerosas personas que pasaban los domingos en las quintas de recreo de esta avenida. Un relato del cronista Daniel de la Vega nos devuelve al ocaso de un domingo de 1921.

El camino de Núñoa, en el anochecer del día festivo, entonces ya tenía animación. Los tranvías regresaban a la ciudad repletos de pasajeros bulliciosos, que traían ramos de flores, paquetes de frutas y alegría del campo (...). [Núñoa] [t]odavía no era el barrio alto de moda. Los faros de los automóviles se cruzaban alegremente, y todo el camino era un río de ciclistas, de caballos, de carruajes, con tranvías con gente que volvía de divertirse. En algunos sitios el vino había hecho olvidar las preocupaciones, y alguien cantaba. Lejos, sonaba quejumbroso un acordeón. (De la Vega, 1962, pp. 84-86)

La idea de un paseo hacia los alrededores por atractivos caminos, para acabar comiendo y descansando en alguna quinta de recreo o fundo vecino, fue probablemente la modalidad más recurrente que adquirió el paseo ocioso durante la década de los veinte. Los numerosos testimonios que se conservan en las revistas de sociedad, de automovilismo y de los gremios del transporte permiten reconstruir a grandes rasgos los elementos comunes que caracterizaban a estos viajes. Uno de los primeros paseos de este tipo se realizó hacia 1916 y su testimonio en la revista Auto y Aero parece haber sentado un precedente para los numerosos paseos que se emprendieron en la siguiente década.

Brillante y magnífico bajo todos conceptos fue el paseo campestre ofrecido a un grupo de sus relaciones por la señorita Rosa Labbé B., en su fundo "La Dehesa”, el viernes 8 del presente.

Esta es una de las primeras ocasiones en Chile en que se ha reunido en una sola iniciativa una hermosa reunión social y una atrayente excursión automovilística.

A las 6 de la mañana partía de Santiago la comitiva, en seis automóviles, llegando en una hora de camino a las casas del fundo, situado al oriente de la capital.

Galantemente atendidos por los dueños de casa, los invitados alternaron sus pasatiempos, entre el tennis, el croquet, la fotografía, el fonógrafo, la hamaca y un animado baile.

Después del espléndido almuerzo, durante el cual reinó la más ruidosa alegría, partió la comitiva otra vez en los automóviles hacia "El Tranque", que es un paraje ideal, situado en el mismo fundo. (...) A las seis de la tarde los excursionistas regresaban a las casas, donde se sirvieron magníficas once, emprendiendo luego el viaje de regreso a la capital aprovechando la noche de luna. ("Paseo campestre", 1916, p. 262)

El esquema al cual se atendría la mayor parte de estos viajes era más o menos el que sigue. Con salida en algún punto central de Santiago entre 6 y 9 de la mańana, se 
daban cita las familias o miembros de asociaciones que participarían en el paseo. Estos grupos podían estar formados por automóviles particulares, motocicletas, automóviles de alquiler o incluso góndolas. En número que podía incluso llegar a formar caravanas de dos hasta más de treinta vehículos, la comitiva emprendía el viaje por alguna de las rutas principales de salida de Santiago. Luego de recorrer caminos de diversa dificultad y belleza y con posibles paradas para descansar, contemplar el paisaje o arreglar algún desperfecto en los vehículos, la procesión arribaba a algún fundo o quinta cuyo dueño (quien en muchas ocasiones era el organizador del paseo) ofrecía su recepción y hospitalidad. Dependiendo de la hora de llegada, el tiempo que se pasaba en este lugar se repartía entre los juegos, el almuerzo y algún posible paseo en automóvil a algún lugar cercano de interés. Para algunos, los juegos practicados eran el croquet y el tenis, mientras para otros se mantenían vigentes los tradicionales de tiro de la cuerda, carreras pedestres, carreras a la chilena, concursos de equitación y la infaltable cueca. El almuerzo, que era ofrecido generalmente por la familia dueńa del lugar, se desarrollaba siempre al aire libre, bajo la sombra de una arbolada o de unos parrones; y en los juegos, la elección dependía de las preferencias culturales del grupo social reunido. Después de un abundante y dilatado almuerzo, era frecuente que los comensales siguieran en sus vehículos al dueño o algún otro conocedor de la zona en alguna excursión breve a un pueblo cercano, alguna vińa, cultivo, o en búsqueda de algún camino pintoresco, vista panorámica o belleza oculta de la naturaleza en el sector. Finalmente, poco antes de que oscureciera, la comitiva emprendía el retorno hacia la capital.

El Cajón del Maipo, Peñaflor, San Bernardo, El Monte, Puente Alto, La Dehesa, Apoquindo, Cajón de Las Condes, Los Andes, Jahuel, Los Guindos, Buin, Cultrín, son solo algunos de los numerosos destinos de los cuales han quedado testimonios de quienes buscaban descanso y distracción en la forma de un paseo campestre. Gracias a los notables avances efectuados en materia de pavimentación de caminos en los alrededores de la capital durante el gobierno de Ibáńez, los tiempos de recorrido y los imprevistos camineros se redujeron, siendo cada vez más fácil llegar a estos destinos. $\mathrm{Al}$ respecto, un medio anunciaba:

Durante el ańo pasado eran interminables las caravanas de automóviles, que conducían turistas y paseantes munidos de skys, bobsleigs, etc., interesados en pasar un día de campo, lejos del aburrimiento de nuestra ciudad. Este año, en que los caminos han sido sensiblemente mejorados, el número será sin duda considerablemente mayor. ("Los paseos a la nieve”, 1930, p. 382)

Además de la mejora de caminos, este interés por los alrededores se refuerza por el gran crecimiento que experimentó el parque de vehículos motorizados en circulación durante el gobierno de Ibánez del Campo. Solo en dos ańos, entre 1927 y 1929, se pasó de 6.893 a 15.654 vehículos motorizados en la comuna de Santiago (Errázuriz, 2014).

Por otra parte, si bien el automóvil particular era el medio idóneo recomendado para llegar a estos lugares, parte significativa de quienes salían de la ciudad no tenía automóvil y recurría a otros medios de transporte, como el tranvía, el ferrocarril, los automóviles de alquiler o los autobuses. Especial importancia adquirieron estos 
últimos. Mientras durante las primeras dos décadas del siglo xx el transporte colectivo había sido monopolizado por los tranvías eléctricos, que habían reemplazado a la mayor parte de los tranvías tirados por animales, hacia mediados de la década de 1920 los autobuses se multiplicaron y cubrieron rápidamente la red de recorridos del tranvía, inaugurando una intensa competencia. Hacia 1926 existían 900 buses que cubrían más de treinta recorridos ("Nómina de recorridos...", 1926). Otro índice que confirma el éxito de este nuevo vehículo era el número de pasajes vendidos por año, que en 1929 alcanzaría los 142 millones frente a los 145 de la Compañía de Tranvías. Sin embargo, para entonces, la cobertura era significativamente mayor, con 392 kilómetros de recorrido contra 257 de los tranvías (Santiago, su pasado..., 1929). Sin necesidad de vías o cableado aéreo para la extensión de sus recorridos, hacia fines de la década del veinte surgirían las primeras flotas de autobuses con recorridos interurbanos. Para septiembre de 1929 existían autobuses con destino a Peñaflor, Maipú, Puente Alto, Renca, Colina, Quilicura, Barrancas, Peralillo, Conchalí, Lonquén, Las Condes, Apoquindo y Parque Riesco. Los horarios variaban según la demanda del recorrido, desde dos salidas diarias en caso de los autobuses con destino a Lonquén, hasta salidas cada 15 minutos para los buses a Renca. (“Orden del Día No 186”, 1929).

\section{Reflexiones finales: hacia una vida de ciudad en el campo}

La popularización del recorrido campestre hacia los alrededores debe ser vinculada al proceso de suburbanización que simultáneamente comenzaron a emprender algunos santiaguinos. Si bien requeriría otro estudio comprobar si los asiduos al paseo campestre y las excursiones fueron los mismos que emprendieron la suburbanización, existen otros nexos más finos en torno a los cuales vale la pena reflexionar. Hacia 1929, en pleno boom del mejoramiento caminero y de los alrededores como destino turístico, una revista seńalaba:

El automóvil está haciendo familiares a la mayoría de los santiaguinos los hermosos paisajes de los alrededores de la ciudad. Providencia, Macul, Apoquindo, San Ramón, no parecen ya una lejanía. ("Por los alrededores de la Capital", 1929)

Efectivamente, por poco más de una década los periódicos, las revistas de sociedad, pero sobre todo las revistas de automovilistas y de los gremios del transporte, venían reportando, mediante testimonios escritos y visuales, las posibilidades y atractivos que ofrecían "los alrededores" para los habitantes de Santiago. En forma paralela, los viajes que inicialmente se calificaban de verdaderas proezas que requerían grandes cantidades de tiempo y energía para su concreción, con el mejoramiento de los caminos y de las tecnologías de transporte habían perdido aquel halo de heroísmo, siendo asociados cada día más al ámbito de lo cotidiano. El campo como paraje natural vinculado a la ventilación, la higiene y el descanso del ajetreo metropolitano, estaba definitivamente más cerca que antes. Y, en ocasiones, la cercanía era tal que los fanáticos de la vida al aire libre consideraban la posibilidad de trasladarse a vivir a los alrededores y, en cierta medida, hacer de cada día un domingo. 
Ahora bien, los alrededores no constituían un paisaje indiferenciado. Entre los distintos destinos, el sector oriente fue visiblemente el más concurrido. Desde tiempos coloniales, debido a la dirección del curso de las aguas del río Mapocho y la situación privilegiada en la disposición de agua abundante y limpia (Piwonka, 1999), el sector oriente había gozado de una positiva valoración. Luego, la temprana explotación agrícola que abastecía a la capital sellaría la cercana dependencia del área con Santiago (León Echaiz, 1972). Esta vinculación cotidiana con el sector oriente es patente al observar los recorridos tranviarios, que -tal como se señaló anteriormente- favorecieron las prácticas ociosas de variados sectores sociales durante los días festivos. Desde fines del siglo XIX, antes de la electrificación del sistema, los únicos recorridos que salían del radio urbano, además de los que se dirigían hacia la salida norte, eran las líneas por las avenidas Providencia e Irarrázaval. Esta situación se mantendría idéntica hasta la proliferación de los autobuses. Tales antecedentes explican la popularidad que adquirieron las quintas de recreo en el camino de Nuñoa, Tobalaba y avenida Ossa, como destino de fin de semana.

Por otro lado, en 1894 un grupo de privados impulsaría un inédito loteo para casas quinta de segunda residencia, destinado a sectores acomodados, que sellaría el destino suburbano del barrio oriente. La Sociedad Población Providencia transformaría la antigua chacra Lo Guzmán en la elegante avenida Pedro de Valdivia, donde se construirían algunos de los más fastuosos palacios y chalets (Sociedad Población Providencia, 1894). La influencia de este loteo se extendió rápidamente hacia los terrenos aledańos y pronto surgieron avenidas como Macul, Ricardo Lyon o Los Leones, donde simultáneamente a las prácticas turísticas se iniciaba un proceso de subdivisión predial para el desarrollo de proyectos inmobiliarios que buscaban transformar estos lugares en barrios suburbanos. ${ }^{1}$ En una caricatura de la revista $Z i g$-Zag en que aparece un gran peladero con la ciudad de fondo a lo lejos, dos hombres conversan sobre el cambiante valor económico y cultural que adquirían los alrededores de Santiago y cómo el fundo que antes no podía venderse en 20 pesos la hectárea, una vez subdividido, era vendido a 240 pesos el metro. Sin importar si estos sitios contaban con servicios de alcantarillas, ni de luz, ni de gas, ni de agua potable, o que estuvieran a varios kilómetros de Santiago, el factor determinante era que "hoy, mister, están de moda los alrededores. Y lo que es moda, no incomoda”. En el cuadro siguiente se ilustraba un gran descampado rodeado de construcciones y bajo esta imagen se leía:

... Y así, mister, a la vuelta de pocos años, usted podrá ver convertido en realidad, aquí en Santiago, ese magnífico sueño de la ciudad circular, con toda la población, trasladada a los alrededores; y lo que es ahora la ciudad, transformada en un peladero que podremos destinar a un gran Estadio Nacional, o simplemente a almacenar aire puro... ("Las aventuras de Mr. Ripeapple", 1926.) Santiago, se pueden consultar los resultados del Fondecyt 1020877: "Valparaíso, Santiago y Concepción: formación de sus barrios altos. Entre la búsqueda de calidad de vida y la construcción de identidad social (1892-1964)". Información en http://w1.conicyt.cl/bases/ fondecyt/proyectos/01/2002/1020877.html 
El discurso pro automovilización, al cual adhirió sin declararlo explícitamente el presidente Ibáñez (Errázuriz, 2014), estaba directamente vinculado al discurso suburbanizador. Ambas proclamas eran respaldadas tenazmente por la política económica norteamericana, que para los años treinta ya ejercía una fuerte influencia cultural en toda América Latina (Joseph, Legrand \& Salvatore, 1998). Entre los numerosos artículos que hablan de la importancia del automóvil para acceder a un nuevo estilo de vida suburbana, la publicación de uno, en un medio vinculado al gobierno local como fue el Boletín Oficial de la Dirección del Tránsito, es ilustrativa del traspaso de estas ideas al contexto nacional.

En otros tiempos, el hombre cuyas actividades estaban en la ciudad, vivía casi el año entero aprisionado entre sus calles. Su sueño de salir a aspirar el aire puro del campo, no podía hacerse realidad sino en el corto período de unas vacaciones y con gran dificultad en algunos días domingos.

Eran domingos excepcionales. Levantábase al alba y sobre un incómodo carruaje, que avanzaba por caminos polvorientos, tenía que hacer una jornada pesadísima para realizar la aspiración de vivir sólo por algunas horas la vida campesina.

El automóvil ha hecho cambiar completamente este aspecto de la vida. Ya no sólo se puede ir al campo cuando se quiera, sino que también se puede vivir en plena campińa aun cuando las actividades de la vida estén en pleno centro de la ciudad. La vida moderna se puede decir que tiende a eso: a alejar la casa habitación de los centros de afiebrada actividad. Y el hombre que durante todo el día está aprisionado entre las calles de la ciudad, puede tener su chalet en pleno campo. Y para sus horas descanso, donde hay mucho aire y mucha belleza en el paisaje. Por eso es que las grandes ciudades se ensanchan, se derraman hacia el valle o hacia la montańa. Porque la ciudad moderna debe toda su grandiosidad al automóvil. ("El auto, el campo y la ciudad", 1928, p. 42)

No se puede afirmar que el paseo campestre a los alrededores sea un antecedente determinante para el proceso de suburbanización que en Santiago toma fuerza desde la década de los veinte. Sin embargo, lo que sí se puede sostener es que la noción de "los alrededores" a la cual se hacía referencia cuando se hablaba del paseo campestre o excursión, encuentra muchos elementos comunes con la noción de "los alrededores" que se asocia a la suburbanización. Cuando se observan algunas imágenes que se utilizan para difundir el consumo del automóvil (figuras 5-10), son muchos los casos en que no es posible distinguir si las construcciones aisladas por la vegetación corresponden a la casa de los dueños del automóvil, a su residencia de veraneo o a algún club deportivo o instalación turística visitada. Hace falta leer el texto que acompaña a la imagen o buscar elementos accesorios, como unos palos de golf, para dilucidar la incógnita.

$\mathrm{Y}$ es que no importa demasiado si se está de paseo o se vive en los alrededores, pues el elemento común que interesa recalcar es el nuevo estilo de vida, distinto del que llevaban quienes diariamente se daban cita en el maicillo del parque Cousiño, en los salones del Club de la Unión o en la misa obligada de cada mañana. Nuevos valores como la libertad y autonomía de movimiento; la importancia del contacto con la naturaleza, del cultivo y cuidado del cuerpo, de la vida familiar, de una mayor 
autonomía de las mujeres, cuestionan los antiguos valores tradicionales que hasta entonces distinguían aquel "modo de ser" de la oligarquía del cambio de siglo. Nuevas vestimentas, nuevos juegos y distracciones y nuevos bailes buscan acercarse a posturas y actitudes de mayor naturalidad y audacia. Es un estilo de vida en donde se proclama la escisión entre trabajo y descanso, entre la vida familiar y la vida pública, entre la ciudad y los alrededores, o entre la ciudad del trabajo y la ciudad del descanso.

Figuras 5-6 | Publicidad de automóviles particulares en la revista Zig-Zag durante la década de 1920

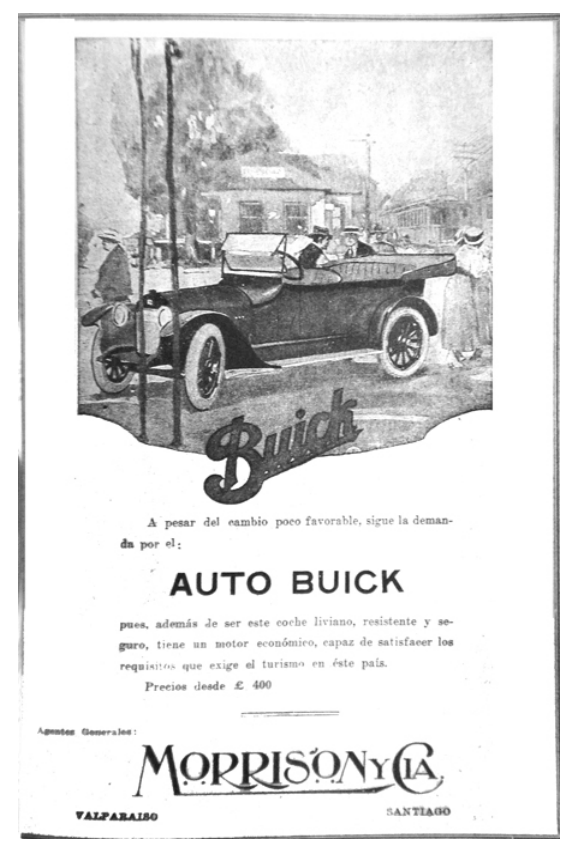
VOL. XIV, NÚM. 730
FUENTE ZIG-ZAG. IS DE FEBRERO, I9I9.

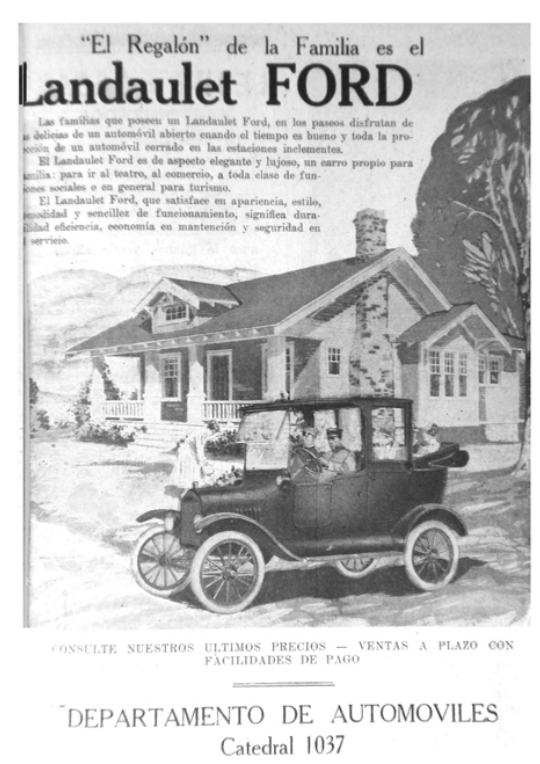

GIBBS \& Co.
FUENTE $Z I G-Z A G .24$ DE ENERO, I920. VOL. XV, NÚM. 779 
FIguras 7-8 | Publicidad de automóviles particulares en la revista Zig-Zag durante la década de 1920

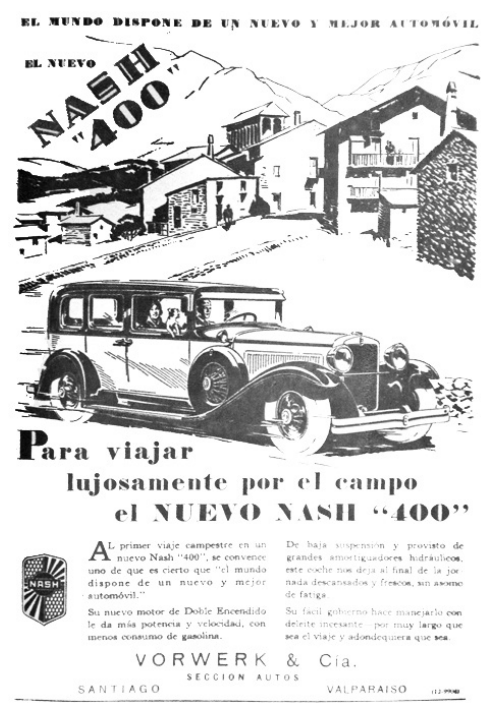

FUENTE ZIG-ZAG. 23 DE FEBRERO, I 929. VOL. XXIV, NÚM. I 253

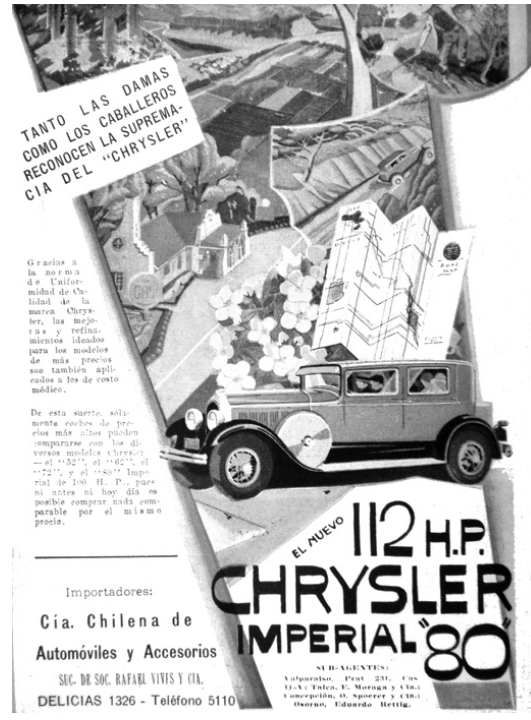

FUENTE ZIG-ZAG. I 4 DE JULIO, I 928. VOL. XXIV, NÚM. I 22 I

Figuras 9 Y io | Portadas de la revista chilena de automovilismo Motor

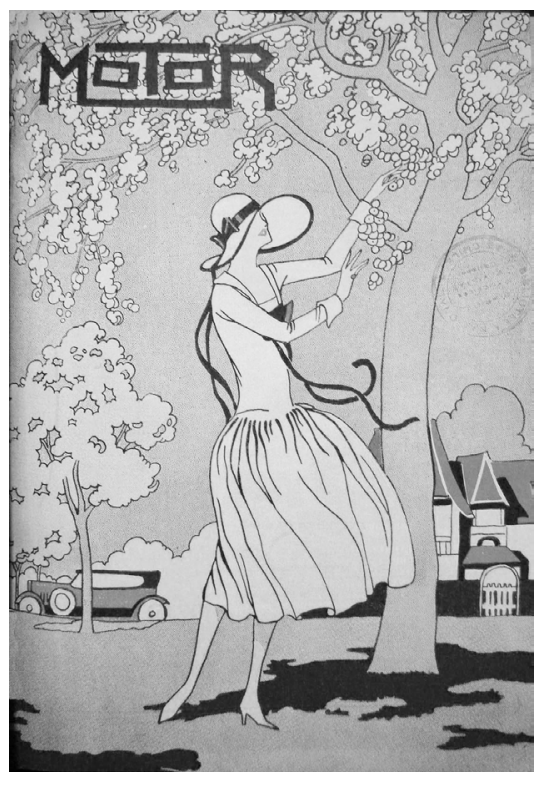

FUENTE MOTOR. REVISTA CHILENA DE AUTOMOVILI 26 DE JUNIO, I 926 VOL II, NÚM I 5.

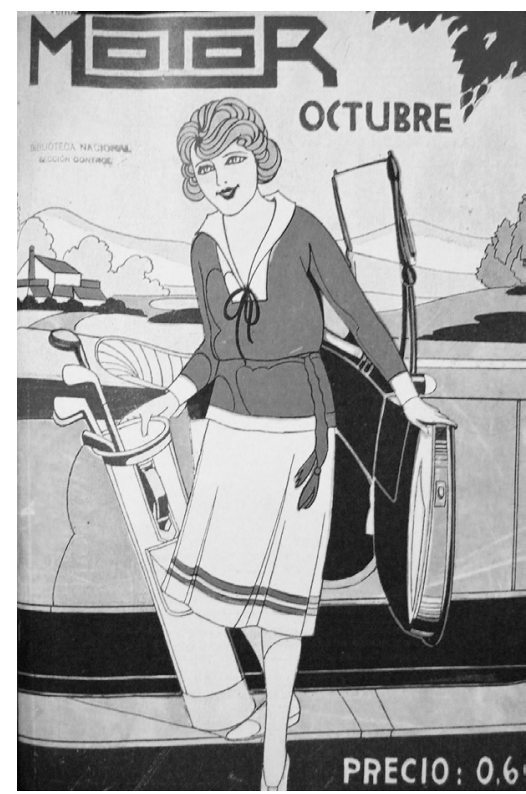

FUENTE MOTOR. REVISTA CHILENA DE AUTOMOVILISMO, 26 DE OCTUBRE, I 926 VOL. II, NÚM. I9, 
Aunque la ciudad siempre ha contado con un alrededor que la limita frente al territorio, como nunca antes la introducción de las nuevas tecnologías de transporte posibilita una concepción de este alrededor como un lugar indispensable para el desarrollo de la vida metropolitana. Más que un espacio de graduación entre la ciudad y el campo, con la reducción temporal de las distancias, los alrededores sobre los cuales cae la influencia directa de la ciudad adquieren un espesor territorial inédito, al cual debe su autonomía de la ciudad. Los alrededores se convierten así en territorios de dilatación hacia donde se distiende la constreñida vida urbana. Ya sea en forma de espacios de especulación inmobiliaria frente a la creciente demanda del suelo urbano o como tranquilo vergel que asegura una cuota periódica de paz y tranquilidad ante la aceleración de la vida moderna, los alrededores se constituyen como un estado intermedio entre campo y ciudad. Como una frontera de intercambio necesario, donde la ciudad puede arrancar trozos de campo o el campo puede penetrar en la intimidad del mundo urbano.

Ahora las barriadas de los alrededores se transforman vertiginosamente. Las campesinas quieren ser señoritas, y compran plumas y cintas. A veces descubren notas de pésimo gusto, pero en esas avenidas, entre el cielo azul y las rosas abiertas, las discusiones sobre estilo no llegan hasta la interjección. El chalet es ahora el amo de esas tierras, y el automóvil su lacayo puntualísimo. Providencia utiliza la electricidad, habla inglés y a ratos padece neurastenia. Por sus calles pavimentadas ya pasó el jazz-band. En las noches, la radiotelefonía le lleva noticias comerciales y estrofas inflamadas.

$\mathrm{Y}$ esto no apena. El campo gusta sin polvo, sin caminata, sin barro, sin espina y sin mosquito. La naturaleza es conmovedora pero detrás de un cristal. Providencia y Ñuńoa lo saben, y todas las mañanas se asoman a un espejo para peinarse los cabellos. Conquistas suyas son la inglesita vestida de blanco, la bombilla eléctrica, la cancha de tennis, el alcantarillado y el vecino millonario. (De la Vega, 1928)

\section{Referencias bibliográficas}

Balneario de Apoquindo. (1921, diciembre 24). Zig-Zag, núm. 879.

Balneario de Apoquindo. (1927, enero). Auto y Aero, núm. 139.

Barros, L. \& Vergara, X. (2007). El modo de ser aristocrático. El caso de la oligarquía chilena hacia 1900. Santiago: Ariadna Ediciones.

Baudrillard, J. (1969). El sistema de los objetos. México, DF: Siglo xxi Editores.

Booth, R. (2009). El camino en Chile. Modernización técnica y transformación territorial en torno a la irrupción del automóvil (1913-1931). Tesis para optar al grado de Doctor en Arquitectura y Estudios Urbanos, Pontificia Universidad Católica de Chile.

Caminos para automóviles. (1917, octubre 15). Auto y Aero, núm. 55.

De la Vega, D. (1928, agosto 11). Los alrededores. Zig-Zag, núm. 11.

De la Vega, D. (1962). Confesiones imperdonables. Santiago: Zig-Zag. 
Dell'Orto, P. (1920, diciembre). Turismo primaveral. Santiago y sus alrededores. Auto y Aero, núm. 125-126.

Edwards Bello, J. (1931). Valparaíso. La ciudad del viento. Santiago: Editorial Nascimento.

El Actual Departamento del Tránsito. Ayer y hoy. Datos estadísticos. (1928, diciembre 7). Boletín Municipal, núm. 996.

El camping. (1917, noviembre 30). Auto y Aero, núm. 58.

Errázuriz, T. (2010, julio-diciembre). El asalto de los motorizados. El transporte moderno y la crisis del tránsito público en Santiago, 1900-1927. Historia, 43 (2), 357-411. En http://dx.doi.org/10.4067/S0717-71942010000200002

Errázuriz, T. (2014, julio-diciembre). La administración de Ibáñez del Campo y el impulso a la circulación moderna (Santiago, 1927-1931). Historia, 47 (2), 313-354. En http:// dx.doi.org/10.4067/S0717-71942014000200002

Fishman, R. (1987). Bourgueois utopias. The rise and fall of suburbia. New York: Basic Books.

García Díaz, G. (1926, noviembre). Balneario Jahuel. El más hermoso de Chile. A 1,180 metros sobre el nivel del mar. Auto y Aero, 137.

García Díaz, G. (1929). El turista. Guía General del Turismo en Chile. Obra indispensable para todo viajero que visite la República de Chile, o quiera recorrer sus diversas regiones. Santiago: Imprenta Universitaria.

Guía del Automovilista. (1920). Auto y Aero.

Hallazgos. (1928, junio). El Chofer, núm. 37.

Joseph, G. M., LeGrand, C., \& Salvatore, R. D. (1998). Close encounters of empire: Writing the cultural history of U.S.-Latin American relations. Durham, NC: Duke University Press.

La Agonía del Verano. (1930, marzo 8). Zig-Zag, núm. 1307.

La gente que va al zoo los domingos. (1939, septiembre 27). Zig-Zag, núm. 1336.

Las aventuras de Mr. Ripeapple. (1929, julio 6). Zig-Zag, núm. 1272.

Las excursiones cortas a los alrededores de Santiago. (1927, noviembre-diciembre). Auto y Aero, núm. 148-149.

Las excursiones. (1916, noviembre 15). Auto y Aero, núm. 33.

León Echaiz, R. (1972). Nuñohue: Historia de Nuñoa, Providencia, Las Condes y La Reina. Buenos Aires: Francisco de Aguirre.

Lira, R. (1955). Los viejos tranvias se van. Antaño y hogaño de la locomoción colectiva: historia, glosas viñetas, estampas, semblanzas y otros relatos. Santiago [s/e].

Lo que es el camping. (1929, septiembre). Auto y Aero, núm. 169.

Los paseos a la nieve. (1930, junio). Auto y Turismo, núm. 178.

Nómina de recorridos para autobuses. (1926, noviembre 2). Boletín Municipal (Santiago), núm. 446.

Nuestros domingos por los alrededores de Santiago - Un paseo a Apoquindo. (1925, abril). Motor, núm. 1.

Orden del Día No 186 de la Prefectura General de Santiago. Numeración de recorridos concluidos o fusionados... (1929, septiembre). El Autobús, núm. 31.

Orrego Luco, L. (1908). Casa Grande. Santiago: Zig-Zag Editores.

Parque Sportivo Pudahuel. Favorito de la alta sociedad. (1917, septiembre 15). Auto y Aero, núm. 53.

Paseo Campestre. (1916, diciembre 15). Auto y Aero, núm. 35. 
Pic-Nic con que la Federación de Chauffeurs de Chile celebra su octavo Aniversario. (1926, enero 15). El Chofer, núm. 8.

Piwonka, G. (1999). Las aguas de Santiago de Chile, 1541-1999. Santiago: Editorial Universitaria.

¡Pobres automovilistas! (1914, diciembre 31). Auto y Aero, núm. 31.

Por los alrededores de la capital. (1929, abril 20). Zig-Zag, núm. 20

Romero, J. L. (2005). Latinoamérica. Las ciudades y las ideas. Buenos Aires: Siglo XXI Editores.

Santiago, su pasado, su presente, su futuro: administración municipal de don Manuel Salas Rodriguez. (1929). Santiago: s/e.

Sennett, R. (1997). Carne y piedra. El cuerpo y la ciudad en la civilización occidental. Madrid: Alianza.

Sheller, M. (2004). Automotive emotions. Feeling the car. Theory, Culture \& Society, 21(4/5), 221-242. doi: 10.1177/0263276404046068

Simmel, G. (2005). La metrópolis y la vida mental. Bifurcaciones, 4 (primavera) [online]. En http://www.bifurcaciones.cl/004/bifurcaciones_004_reserva.pdf

Sociedad Editora Internacional. (1910). Manual del Viajero. Baedeker de la República de Chile. Santiago de Chile: Imprenta y Litografía América.

Sociedad Población Providencia. (1894). Libro de Actas. Segunda sesión del Directorio en 31 de diciembre.

Thrift, N. (2004). Driving in the city. Theory, Culture \& Society, 21 (4/5), 41-59. doi: $10.1177 / 0263276404046060$

Tornero, C. (1930). Manual del Viajero. Baedeker de la República de Chile. Santiago: Ministerio de Fomento.

Urry, J. (2004). The system of automobility. Theory, Culture \& Society, 21 (4/5), 25-39. doi: $0.1177 / 0263276404046059$

Vamos a la nieve. (1929, junio). Auto y Turismo, núm. 166.

Vida Automóvil: Hotel El Peñaflor. (1917, noviembre 39). Auto y Aero, núm. 58.

Vida Automóvil: Parque Sportivo Pudahuel. (1917, agosto 31). Auto y Aero, núm. 52.

Williams, R. (2001). El campo y la ciudad. Buenos Aires/Barcelona/México, DF: Paidós.

Wirth, L. (2005). El urbanismo como modo de vida. Bifurcaciones [en línea], núm. 2 [otoño]. En http://www.bifurcaciones.cl/002/bifurcaciones_002_reserva.pdf 
TRIBUNA 